\title{
Detecting p53 family proteins in haemocytic leukemia cells of Mytilus edulis from Pictou Harbour, Nova Scotia, Canada
}

\author{
S.D. St-Jean, R.E. Stephens, S.C. Courtenay, and C.L. Reinisch
}

\begin{abstract}
Evaluating patterns of expression of p53-related proteins in cells is a novel approach in defining environmentally linked diseases. We have examined the induction of haemocytic leukemia in Mytilus edulis by municipal and industrial contaminants in Pictou Harbour, Nova Scotia, Canada. We used a murine monoclonal antibody, 1E10, as a diagnostic reagent to detect leukemic cells. We first characterized the reactivity of $1 \mathrm{E} 10$ with both normal and leukemic Mytilus haemocytes by confocal microscopy. We then compared p53 gene family expression (p53, p63-p73, and p97) in normal versus leukemic haemocytes using a panel of monoclonal and polyclonal antibodies to p53 family proteins. The immunochemical data demonstrate that haemocytic leukemia cells of M. edulis differentially express p63p73 and p97-p120 proteins. We subsequently used 1E10 to diagnose haemocytic leukemia in 500 M. edulis previously deployed 6 months earlier in Pictou Harbour. In the field, Mytilus caged near untreated municipal wastewater and bleached kraft pulpmill effluents have a significantly greater chance of developing haemocytic leukemia than do mussels exposed to reference sites.
\end{abstract}

Résumé : L'évaluation des patterns d'expression des protéines de type p53 dans les cellules est une méthodologie nouvelle pour caractériser les maladies liées à l'environnement. Nous avons suivi l'induction de leucémie hémocytique chez Mytilus edulis par des contaminants municipaux et industriels dans le port de Pictou, Nouvelle-Écosse, Canada. Nous avons utilisé un anticorps monoclonal de souris, 1E10, comme réactif diagnostique pour déceler les cellules leucémiques. Nous avons d'abord caractérisé la réactivité de $1 \mathrm{E} 10$ avec des hémocytes normaux et leucémiques de Mytilus par microscopie confocale. Nous avons ensuite comparé l'expression des gènes de la famille p53 (p53, p63-p73 et p97) dans les hémocytes normaux par comparaison aux hémocytes leucémiques au moyen d'une gamme d'anticorps monoclonaux et polyclonaux dirigés contre les protéines de la famille p53. Les données immunochimiques démontrent que les cellules affectées de leucémie hémocytique de M. edulis ont une expression différente des protéines p63-p73 et p97-p120. Nous avons ensuite utilisé 1E10 pour déceler la leucémie hémocytique chez $500 \mathrm{M}$. edulis placés six mois auparavant dans le port de Pictou, Nouvelle-Écosse. En nature, les Mytilus encagés près des eaux municipales de rejet non traitées et les effluents de papetières à procédé kraft ont une probabilité significativement plus grande de développer une leucémie hémocytique que les moules exposées à des sites témoins.

[Traduit par la Rédaction]

\section{Introduction}

Haemocytic leukemia is a fatal disease that occurs in many molluscan species. The disease in molluscs was first diagnosed as a haematopoietic neoplasm Farley (1969). More recently, Miosky et al. (1989) and Kelley et al. (2001) have redefined haematopoietic neoplasm in Mya arenaria as a leukemia based on the overall pathogenesis of the disease. Yet, intense controversy remains among pathologists concerning the precise diagnosis of this disease. In clams, the terminology was reviewed by McGladdery and Bower (1999).
Most recently, the Registry of Tumors in Lower Animals is entering cases diagnosed as leukemia as Leukemia:Systemic. New suggestions have included using disseminated neoplasia or haemocytic leukemia to indicate the putative cell of origin, the haemocyte. Based on our experience with monoclonal antibodies (Reinisch et al. 1983; Miosky et al. 1989), we have modified our use to include the word haemocytic.

Haemocytic leukemia has been reported in Mytilus subspecies along the northwest coast of the United States (Mix 1983; Elston et al. 1988; Krishnakumar et al. 1999), the United Kingdom (Green and Alderman 1983), Denmark

Received 16 August 2004. Accepted 10 March 2005. Published on the NRC Research Press Web site at http://cjfas.nrc.ca on 1 September 2005.

$\mathrm{J} 18265$

S.D. St-Jean. ${ }^{1}$ Environment Canada, National Water Research Institute, 867 Lakeshore Road, Burlington, ON L7R 4A6, Canada. R.E. Stephens. Department of Physiology and Biophysics, Boston University School of Medicine, 715 Albany Street, Boston, MA 02118, USA.

S.C. Courtenay. Fisheries and Oceans Canada, 343 University Avenue, Moncton, NB E1C 9B6, Canada.

C.L. Reinisch. Laboratory of Aquatic Biomedicine, Marine Biological Laboratory, Woods Hole, MA 02543, USA.

${ }^{1}$ Corresponding author (e-mail: Sylvie.St-Jean@ec.gc.ca). 
(Rasmussen 1996), Spain (Alonso et al. 2001), Chile (Camplans et al. 1998), Italy (Zizzo et al. 1991), and southern British Columbia (Wong et al. 1984; Bower 1989). Haemocytic leukemia outbreaks in Mya have been documented in Chesapeake Bay (Farley et al. 1986), New Bedford Harbour (Reinisch et al. 1984), Long Island Sound (Brousseau 1987), and Prince Edward Island (McGladdery et al. 2001). In Prince Edward Island, for example, areas with haemocytic leukemia are subject to high agricultural runoff and (or) organochlorine wastes. Despite these many examples, the cause of molluscan haemocytic leukemia remains unresolved (Hillman 1993). Possible etiologies include the induction by environmental carcinogens and promoters and (or) infectious agents (Oprandy et al. 1981).

The most intensively studied molluscan haemocytic leukemia is that of $M$. arenaria, the soft-shell clam. Haemocytic leukemia in $M y a$ is characterized by proliferating tumour cells in the haemolymph that have a high nuclear to cytoplasmic ratio. In end-stage disease, concentrations of haemocytic leukemia cells (HL) can reach $2 \times 10^{8}$ cells.mL haemolymph ${ }^{-1}$. We developed a monoclonal antibody MAB $1 \mathrm{E} 10$ initially as a diagnostic reagent to detect haemocytic leukemia in the haemolymph of populations of $M$. arenaria (Reinisch et al. 1983). More recently, we extended these studies to investigate the structure of the protein recognized by $1 \mathrm{E} 10$ (Stephens et al. 2001). By primary structural analysis, we showed that the $1 \mathrm{E} 10$ antigen is a $252-\mathrm{kDa}$ glycoprotein that shares homologies with spectrin-dystrophin and talin. These properties strongly suggest that the 1E10 structure is a transmembrane protein with potential cytoskeletal connections (Stephens et al. 2001).

Stephens et al. (2001) and Kelley et al. (2001) further characterized haemocytic leukemia cells from $M$. arenaria using monoclonal and polyclonal antibodies to proteins of the p53 gene family. p53 genes (53, 63-73, 97, and 120) regulate cell division and differentiation and are extremely important in pathways leading to either cell death or malignancy. While normal haemocytes of Mya express p53 and p97 but not p73, haemocytic leukemia cells express p53 and p73 but become p97 negative. We also identified an intermediate or transitional haemocyte in $M y a$, a cell that expresses the 2A4 antigen recognized by a murine monoclonal antibody (White et al. 1993).

Much less is known at either the molecular or cellular level about haemocytic leukemia in the blue mussel Mytilus edulis. Haemocytic leukemia in Mytilus was studied by Noel et al. (1994) who developed a panel of monoclonal antibodies that specifically recognize leukemic Mytilus haemocytes. These reagents, as well as molecular probes, provide far more sensitivity than does classic histopathology in detecting low numbers of abnormal cells or genes. The application of new technologies allows a far more accurate determination of marine and, ultimately, ecosystem health.

In this paper, we first documented that the murine monoclonal antibody 1E10 was specifically reactive with Mytilus haemocytic leukemia cells. Next, we compared the reactivity of Mytilus and Mya haemocytes on immunoblots using antibodies to different p53 gene family products. We also quantified protein differences in Mytilus by SDS-PAGE, finding the same distinctions as in Mya. We then used 1E10 to examine the haemolymph of Mytilus that had been deployed
6 months previously at 14 sites in and around Pictou Harbour, Nova Scotia, a site heavily contaminated with industrial and municipal wastes (Painter and Stewart 1992). The data suggest that haemocytic leukemia is potentially induced in Pictou Harbour by environmental contaminants but do not rule out a viral component.

\section{Materials and methods}

\section{Haemolymph assessment}

To determine if 1E10 could be used as a diagnostic reagent, we collected M. edulis from Pictou Harbour and analyzed them in 2001. The haemolymph was collected and screened by phase-contrast microscopy. The presumed leukemic cells were then fixed in $1 \%$ formalin, shipped to Woods Hole, Massachusetts, washed, and treated with a panel of monoclonal or polyclonal antibodies. The first set of analyses on cells from six $M$. edulis indicated that $1 \mathrm{E} 10$ was selectively reactive with a subset of haemocytes from Pictou Harbour. Based on those results, we designed this study and repeated these analyses with extensive controls.

In 2002, 1680 blue mussels were collected from a clean site, Malagash Bay, Nova Scotia, and caged at 14 different sites in industrialized Pictou Harbour. Malagash is a small harbour with no industrial input and is sparsely populated. Prior to the transfer, the mussels were tested by the molluscan health section of Fisheries and Oceans Canada and declared disease free. Each mussel was bled using a sterile 23-gauge needle inserted directly into the posterior adductor muscle sinus. One tenth of a millilitre ot haemolymph was extracted into a dry 3-mL syringe and a preliminary diagnosis immediately performed using phase-contrast microscopy at $63 \times$ magnification. Haemocytic leukemia was initially assessed by cell morphology and by cell number using a haemocytometer. To confirm the diagnosis of haemocytic leukemia, we rebled mussels and fixed the haemolymph in modified Barker's formol calcium that contained $4 \% \mathrm{v} / \mathrm{v}$ formaldehyde, $2 \% \mathrm{w} / \mathrm{v}$ sodium chloride, and $1 \% \mathrm{w} / \mathrm{v}$ calcium acetate diluted in high-salt Tris-buffered saline (high salt). The resulting samples were stored in 2-mL Eppendorf tubes, numerically coded, and sent to Woods Hole where assays were performed along with presumed negative samples. Thus, every sample with a preliminary diagnosis of haemocytic leukemia was retested in Woods Hole along with negative samples using either controls or monoclonal antibody $1 \mathrm{E} 10$ to confirm the diagnosis.

Samples were subsequently spun three times for $5 \mathrm{~min}$ in high salt at $3000 \mathrm{rpm}$ using an Eppendorf model 5415C microfuge (Ependorf AG, Hamburg, Germany). Either highsalt solution, monoclonal antibody $1 \mathrm{E} 10$ (1:5), or normal mouse IgG was added to pelleted cells as previously described (Reinisch et al. 1983). The samples were then incubated on a rocker at $10{ }^{\circ} \mathrm{C}$ overnight, spun three times in high salt, and a 1:100 dilution of tetramethylrhodamineconjugated (RITC) rabbit antimouse IgG (Molecular Probes, Eugene, Oregon) added to each sample. All antibodies were spun at $10000 \mathrm{r} \cdot \mathrm{min}^{-1}$ for $20 \mathrm{~min}$ prior to use to remove aggregates. The cells were then incubated an additional $2 \mathrm{~h}$ at $10^{\circ} \mathrm{C}$, washed three times, and evaluated using an Olympus BH2 microscope (Olympus Corporation, Tokyo, Japan) at $500 \times$ magnification using a rhodamine filter. Any positive 
samples were then visualized at an excitation wavelength of $488 \mathrm{~nm}$ using a Zeiss LSM 510 laser scanning confocal microscope (Zeiss, Oberkochen, Germany). In each analysis, normal IgG as well as high-salt solution were used to control for nonspecific binding of the secondary antibody or background signal.

\section{Antibodies}

Murine monoclonal antibody $1 \mathrm{E} 10$ that recognises $M$. arenaria haemocytic leukemia cells was developed as previously described (Reinisch et al. 1983). Murine monoclonal antibody 2A4 that recognizes Mya normal and intermediate haemocytes was developed as previously described (White et al. 1993). A rat monoclonal antibody to the beta subunit of tubulin (clone TUB 2.1) was obtained from ICN (Irvine, California). The universal p53 antibody Ab-1 (clone PAb421) was purchased from Calbiochem (La Jolla, California). An affinity-purified rabbit polyclonal peptide antibody to the $M$. arenaria (soft-shell clam) p53 family (p53-73) was the kind gift of Dr. Charles Walker (Department of Zoology, University of New Hampshire, Durham, NH 03824, USA). An affinity-purified rabbit polyclonal peptide antibody to the unique homology domain of p63p73 (not present in p53) using the Spisula solidissima (surf clam) sequence (Cox et al. 2003) was prepared by New England Peptide, Inc. (Fitchburg, Massachusetts).

\section{Sample preparation}

Liquid nitrogen frozen pellets of haemocytes from individual mussels were mixed rapidly with $20 \mu \mathrm{L}$ of $0.1 \mathrm{~mol}$ phenylmethylsulfonyl fluoride $\cdot \mathrm{L}^{-1}$ in isopropanol and $0.4 \mathrm{~mL}$ of SDS sample buffer (2\% SDS, $0.125 \mathrm{~mol}$ Trisglycine $\cdot \mathrm{L}^{-1}, \mathrm{pH}$ 6.8, $1 \%$ 2-mercaptoethanol, $10 \%$ sucrose), sonicated with a microprobe at $10 \mathrm{~W}$ for $30 \mathrm{~s}$ (Sonicator model W-10), and boiled for $>3 \mathrm{~min}$. The samples were frozen at $-20{ }^{\circ} \mathrm{C}$, thawed, and spun at room temperature for $10 \mathrm{~min}$ at $14000 \mathrm{r} \cdot \mathrm{min}^{-1}$ (Eppendorf model 5415C) to remove insoluble debris. The resulting supernatants were removed and stored at $-80{ }^{\circ} \mathrm{C}$ until use.

\section{SDS-PAGE and immunoblot analyses}

Samples were routinely analyzed on 1.5 -mm-thick smallformat conventional SDS $-8 \% \mathrm{~T} / 2.5 \mathrm{C}$ (8\% total acrylamide of which $2.5 \%$ is cross-linker) polyacrylamide gels using the method of Laemmli (1970). For greater resolution in the high molecular weight region, low cross-linked $(8 \% \mathrm{~T} / 1 \% \mathrm{C})$ polyacrylamide was used (Stephens et al. 2001). Gels were stained with Coomassie Brilliant Blue R-250 (Serva No. 35051) using the equilibrium method of Fairbanks et al. (1971). Immunoblotting to nitrocellulose was carried out by the renaturing method of Dunn (1985) followed by blocking with $1 \%$ bovine serum albumin (BSA) and 5\% nonfat dry milk in Tris-buffered saline, a 1-h incubation with primary antibodies at dilutions specified in the text below, and detection with an alkaline phosphatase coupled secondary antibody and Western Blue stabilized substrate (both obtained from Promega Corporation, Madison, Wisconsin). Glycoproteins were detected on nitrocellulose blots with a glycoprotein detection kit from BioRad Laboratories (Hercules, California) (No. 170-64900). Video densitometry was used for quantification of stained gels and immunoblots as de- scribed in detail elsewhere (Stephens 1997 and references therein). Graphical analyses of densitometric data were performed with SigmaPlot 5.0 (SPSS, Inc., Chicago, Illinois) using its spreadsheet function to normalize band amount and position.

\section{Study area}

Pictou Harbour, located in northern Nova Scotia, is an important commercial estuary and has a history of environmental contamination dating back to the 1800s (Painter and Stewart 1992). These authors conducted an assessment of the environmental quality of Pictou Harbour and surrounding watershed (Painter and Stewart 1992), which evaluated all available information on the quality of waters, sediments, and biota and reported a variety of environmental problems. The following concerns for both Pictou Harbour and the East River were reported: high fecal coliform concentrations causing shellfish harvesting and beach closure, the presence of pollutants, such as metals and organic compounds including polycyclic aromatic hydrocarbons, polychlorinated biphenyls and furan, in the sediments, and dioxin and furan residues in shellfish and crustaceans from Pictou Harbour. Several studies have concentrated on contaminants in Pictou Harbour. For example, Dalziel et al. (1993) examined contamination in the sediment and water column and found slightly elevated heavy metal loads in the Pictou Harbour Pictou Road sediments: $1-56 \mathrm{mg} \mathrm{Cu} \cdot \mathrm{kg}$ dry weight ${ }^{-1}, 0.01-$ $0.85 \mathrm{mg} \mathrm{Hg} \cdot \mathrm{kg}$ dry weight ${ }^{-1}, 5-57 \mathrm{mg} \mathrm{Pb} \cdot \mathrm{kg}$ dry weight ${ }^{-1}$, and $7-231 \mathrm{mg} \mathrm{Zn} \cdot \mathrm{kg}$ dry weight ${ }^{-1}$. Prouse (1994) ranked Pictou Harbour the fourth most contaminated harbour among 14 examined in the Maritimes for polycyclic aromatic hydrocarbons levels in American lobster (Homarus americanus), and St-Jean et al. (1999) reported levels of tributyltin reaching $250 \mathrm{ng} \cdot \mathrm{g}^{-1}$ in whole-mussel tissue. In addition, St-Jean et al. (2003) reported accumulations of several metals in mussels caged throughout Pictou Harbour: up to $31 \mu \mathrm{g} \mathrm{Al} \cdot \mathrm{g}$ wet weight ${ }^{-1}, 3.6 \mu \mathrm{g} \mathrm{As} \cdot \mathrm{g}$ wet weight ${ }^{-1}$, $4.0 \mu \mathrm{g} \mathrm{Cu} \cdot \mathrm{g}$ wet weight ${ }^{-1}, 68 \mu \mathrm{g} \mathrm{Fe} \cdot \mathrm{g}$ wet weight ${ }^{-1}$, $9.6 \mu \mathrm{g} \mathrm{Mn} \cdot \mathrm{g}$ wet weight ${ }^{-1}$, and $26 \mu \mathrm{g} \mathrm{Zn} \cdot \mathrm{g}$ wet weight ${ }^{-1}$. The sites from that study corresponded to sites PS1, PM-A, PMB, LH, and LP from this study (see below).

\section{Site selection and cage positions}

The location of the various effluent types examined in this study are shown in Fig. 1. Along the East River, the frames at New Glasgow bridge were positioned approximately $100 \mathrm{~m}$ from the source point, which consist of a steel plant and buried city dump. The frames at a secondary-treated municipal wastewater site were positioned approximately $3 \mathrm{~m}$ from the source point (i.e., from the pipe outfall) of the secondary-treated municipal wastewater site. The frames at a coal-generated electrical powerplant were positioned approximately $300 \mathrm{~m}$ from the discharges of the effluent from the power plant. The frames at Mussel Point were positioned at the confluence of the East River and Pictou Harbour and assessed the cumulative contribution of the East River as well as the extent of the raw sewage plume.

In Pictou Harbour, frames were positioned in a gradient to assess the contribution of raw sewage (PS1, PS2, PS3, PS4, and PS5): there are two pipes discharging raw sewage from Pictou (population of 5000), one situated at PS2 (main dis- 
Fig. 1. Sampling sites around Pictou Harbour, Nova Scotia, Canada. NG, New Glasgow (steel plant and buried city dump); STMW, secondary-treated municipal wastewater; PP, power plant (coal-operated power generation); MP, Mussel Point; PS1-PS5, raw sewage discharged by the Town of Pictou (outfall on PS2 and PS3); LH, Light House; pulpmills A and B, both 500 and 1000 m from pulpmill discharge; LP, Logan Point (reference site); MER, Merigomish (reference site) and Malagash (reference stock population).

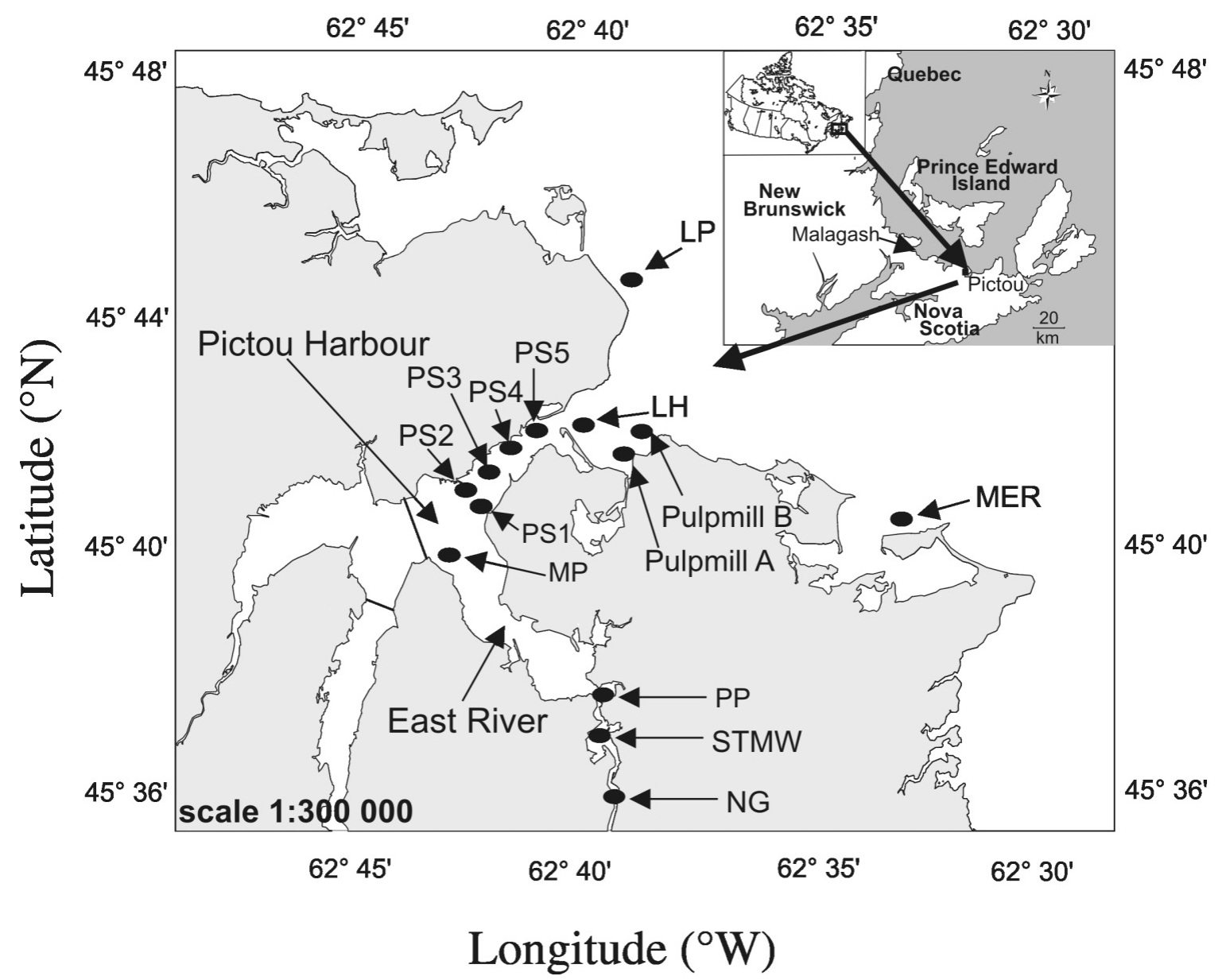

charge) and the second at PS3; thus, PS3 receives inputs from both outfalls. All of the PS frames were positioned in a 300-m interval gradient starting from PS2 and Mussel Point was positioned approximately $500 \mathrm{~m}$ from PS2.

For Pictou Road, the frames at Light House were positioned close to the narrow passage between Pictou Harbour and Pictou Road and monitored the extent of the Pictou Harbour contribution as well as the pulp mill effluent. Two frames were positioned in a gradient from the pulpmill effluent (pulpmills A and B). The frames were positioned 500 and $1000 \mathrm{~m}$, respectively, from the discharge point of bleached kraft mill pulp and paper mill effluent into Pictou Road.

Mussels were also placed at two sites outside the harbour (LP and MER). LP is potentially under intermittent, or at least reduced, influence from Pictou Harbour, while MER is not under any harbour influence and was chosen to serve as a reference site.

All sites situated along Northumberland Strait, where the mussels originate, are designated pure populations of M. edulis with no Mytilus trossulus present (Mallet and Carver 1995). Morphometric measurement techniques developed by Mallet and Carver (1995) were repeated to confirm the identity of M. edulis.

\section{In situ monitoring}

In early March 2002, 1680 mussels measuring between 6 and $8 \mathrm{~cm}$ (adults) were collected from Malagash Bay. Upon arrival at the laboratory facilities in Pictou, the mussels were individually screened for size and loaded into socks (10 mussels per sock), each separated by cable ties. The socks were randomly divided among 28 frames (two frames per site). Each frame, made of ABS plumbing-grade tubing, held six socks for a total of 60 mussels per cage. The frames were deployed $2 \mathrm{~m}$ from the bottom in 4.5-m-deep waters in late March and retrieved for assessment in early October 2002, ensuring an exposure period of 6 months. Following retrieval, the mussels were transported to the laboratory and held before evaluation in a cooler containing water from the individual collection sites. Any dead or moribund mussels were discarded. A minimum of 28 mussels was assessed per site. In early July, the mussels spawned.

\section{Statistical analysis}

Owing to the nature of the data (assessments ranked in categories rather than continuous measures), we compared the levels of haemocytic leukemia at each site with the levels found at the reference site using the Kruskal-Wallis (KW) nonparametric analysis of variance test. The analysis was 
followed by a two-tailed nonparametric multiple comparison testing the rank mean of each site against the reference population (MER) independently (Zar 1984).

\section{Results}

\section{Confocal microscopy}

Haemolymph from four mussels from the Mussel Point and four mussels from the New Glasgow site were isolated for confocal analysis. Haemocytes from the Mussel Point site did not react with 1E10 (Figs. 2A.1 and 2B.1). In contrast, a majority of haemocytes from the New Glasgow site were specifically reactive (Figs. 2C.1 and 2D.1). These are typically large, rounded cells showing both plasma membrane and internal vesicular staining. Unstained cells were often irregular (Figs. 2C and 2D, arrows). One out of 70 Mussel Point cells stained with 1 E10 versus 36 out of 68 New Glasgow cells. There was no reactivity above background when any cell population was incubated with either normal mouse IgG or high-salt solution as a first step.

We further evaluated haemocytic leukemia cell reactivity with the murine monoclonal 2A4, polyclonal Ab-1 (pan specific p53), and the rabbit homodomain antibody (p63-p73). As a control for background staining with the homodomain antibody, normal rabbit serum at the same protein concentration was used and the samples were processed with goat antirabbit RITC. Independent analyses showed that Mytilus haemocytic leukemia cells did not specifically react with 2A4, Ab-1, or the rabbit homodomain antibody to p63-p73. However, all but the first can detect antigen on immunoblots (below), suggesting specificity for denatured proteins.

Taken together, the data show that Mytilus haemocytic leukemia cells react specifically with murine monoclonal antibody (1E10) generated to $M$. arenaria haemocytic leukemia cells. In the next series of experiments, we analyze expression of p53 gene family members as well as structural proteins using Western blotting and quantitative SDS-PAGE.

\section{Western blot analyses}

Several pan-specific antibodies reveal key differences between normal and haemocytic leukemia cells in Mytilus haemocytes (Fig. 3) when analyzed at equal protein loadings (equivalent stained gels in Fig. 4). Tubulin is more prevalent by a factor of more than 3 in the presumably more rapidly dividing haemocytic leukemia cells. Similar ratio differences are seen with antibodies that recognize variants of the p53 gene family. A widely used antibody to p53 detects no 53$\mathrm{kDa}$ protein in either cell type but does cross-react with a $120-\mathrm{kDa}$ variant found almost exclusively in haemocytic leukemia cells. An antibody to the unique homology domain of the p63-p73 branch also shows a three- to four-fold greater amount of p63 in haemocytic leukemia cells. An antibody to a common region of the family also confirms the absence of significant amounts of p53 protein while detecting p63, p73, and a number of higher molecular weight variants, likely arising by posttranslational modifications (Cox et al. 2003). Although similar, this pattern is more complex than in Mya, where normal cells uniquely express a $97-\mathrm{kDa}$ protein, while haemocytic leukemia cells exclusively express p73, with p53 remaining constant (Stephens et al. 2001). We provide a compilation of the reactivity of normal and haemocytic leu- kemia $M$. edulis and Mya arenaria haemocytes on immunoblots using both monoclonal and polyclonal antibodies (Table 1).

\section{Protein analysis}

We next compared the protein content and composition of haemocytes from Mya and Mytilus. Sixteen M. edulis haemocyte samples processed by conventional SDS-PAGE revealed a wide variation in total protein yield, ranging from $<0.1$ to $>2 \mathrm{mg}$ per individual (result not shown). The lowprotein samples were very similar in polypeptide composition, as were three very high samples. Intermediate- and high-protein samples closely resembled the profile of M. arenaria haemocytic leukemia cells.

To conveniently compare protein composition qualitatively, we diluted the sample of highest protein content and ran it in parallel with normal haemocytes obtained from uncontaminated Cape Cod waters (Fig. 4). When loaded at equal actin content and analyzed on a low cross-linked SDS-PAGE system to better resolve high molecular weight proteins, characteristic differences become apparent by simple inspection of juxtaposed lane photographs. Normal cells uniquely contain a high molecular weight protein $(\mathrm{N}, \sim 300 \mathrm{kDa})$. Haemocytic leukemia cells contain material that barely penetrates the gel (HMW) and also contain a prominent protein of $\sim 250 \mathrm{kDa}$ (E), which runs as a doublet. Many additional lower molecular weight proteins further distinguish the two cell populations in this side-by-side comparison.

To refine the comparison and obtain quantitative information, we combined two additional samples, appropriately diluted them, and mixed them with an equivalent amount of normal cell extract for SDS-PAGE analysis (Fig. 5A). The characteristic proteins $\mathrm{N}$ and $\mathrm{E}$, a second band ( $\left.\mathrm{E}^{\prime}\right)$ now resolved in haemocytic leukemia cells from a band common to both, a large protein consistently diminished in haemocytic leukemia cells (A), and six additional proteins (asterisks) are noted. All of these have counterparts that distinguish normal from haemocytic leukemia cells in M. arenaria (Stephens et al. 2001).

The most obvious differences occur in the high molecular weight region (Fig. 5B) and several of these differences can be easily evaluated by densitometry after normalization (Fig. 5C). As was true in Mya, protein $\mathrm{N}$ is present only in normal cells, while protein E, the equivalent of the $252-\mathrm{kDa}$ $1 \mathrm{E} 10$ antigen of $M y a$, is characteristic of haemocytic leukemia cells. The latter protein in Mya is often observed as an equimolar doublet, and therefore, $\mathrm{E}^{\prime}$ in Mytilus may correspond to the second Mya $1 \mathrm{E} 10$ band. Conversely, the $165 \mathrm{kDa}$ band $\mathrm{A}$ is diminished, although not absent, in haemocytic leukemia cells, and consequently, it may be the equivalent of the $185-\mathrm{kDa} 2 \mathrm{~A} 4$ antigen in Mya normal cells. However, neither putative equivalent in Mytilus, E or A, was cross-reactive with the corresponding Mya antibody by immunoblotting and neither proved to be significantly glycoslyated (data not shown), a factor that, in addition to species affinity differences, may influence cross-reactivity or renaturation.

\section{In situ monitoring}

During the course of the exposure, the cage positioned at PS4 moved slightly outside the channel and thus outside the 
Fig. 2. Normal and leukemic haemocytes from Mytilus edulis collected from either Mussel Point (MP) or the buried city dump (NG) treated with murine monoclonal antibody $1 \mathrm{E} 10$ and analyzed with laser scanning confocal microscopy. The images were obtained using Karl Zeiss LSM 510 software. (A) Mussel No. 1 from MP; (B) mussel No. 2 from MP; (C) mussel No. 5 from NG; (D) mussel No. 8 from NG. Left panels: fluorescence image; right panels: Nomarski differential interference contrast image. Arrows in Figs. 2C and 2D indicate typical 1E10-negative cells. Scale bars $=5 \mu \mathrm{m}$.
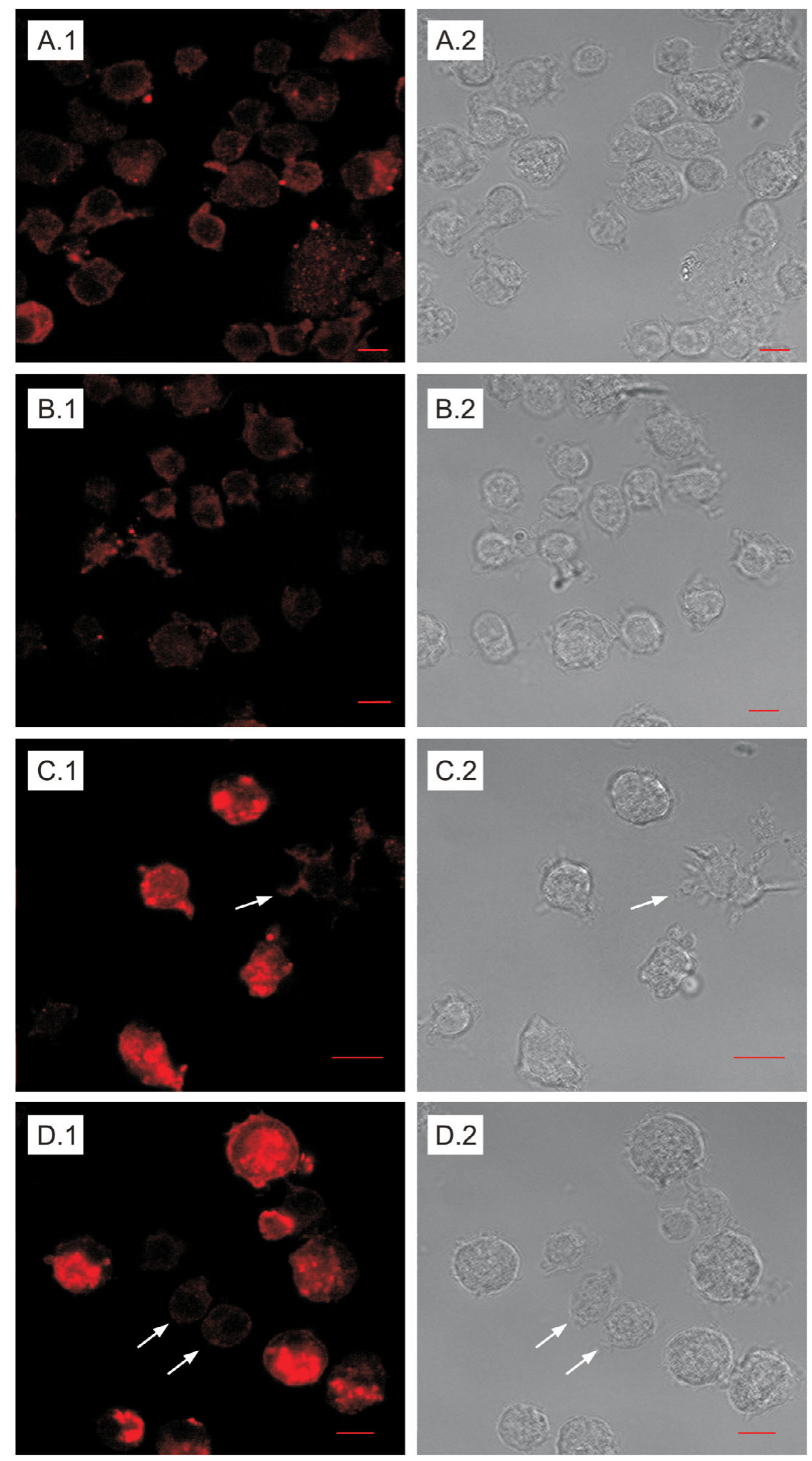
Fig. 3. Comparative antibody cross-reactivity of Mytilus normal (N) and haemocytic leukemia (L) haemocytes at equivalent protein loading. Tubulin, mouse monoclonal TUB 2.1 (to rat beta chain; Gozes and Barnstable 1982) used at 1:1000 dilution; p53, mouse monoclonal Ab-1 (to human; Harlow et al. 1981) used at 1:100; p53-p73, rabbit polyclonal to a 23aa Mya peptide sequence from Kelley et al. (2001) used at 1:1000; p63-p73, rabbit polyclonal to a Spisula p63-p73 homology domain defined by Jessen-Eller et al. (2002) and Cox et al. (2003) used at 1:200. MW, molecular weight standards; asterisks, actin "ghosts" detected by p53-p73 antibody verifying equivalent protein loading.

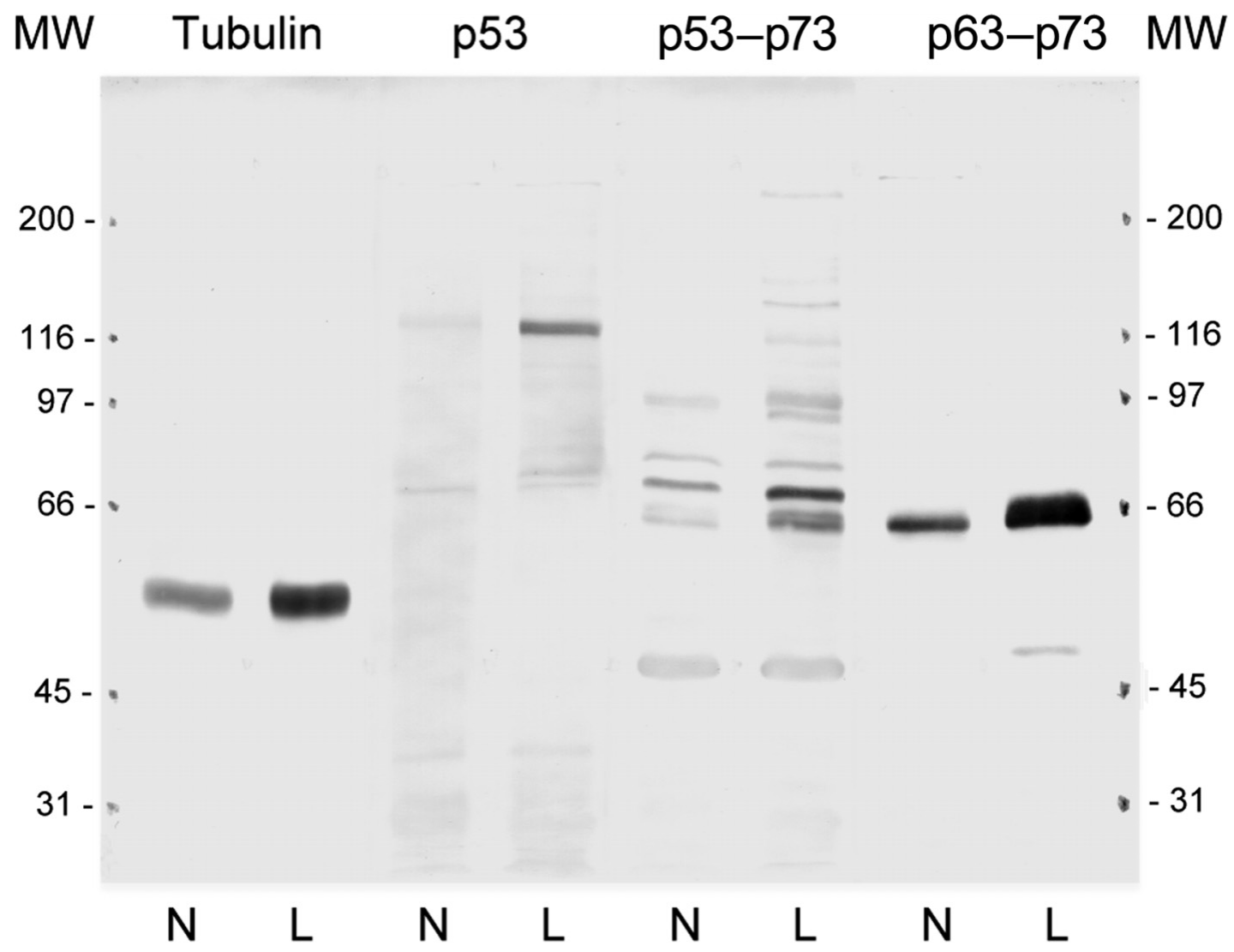

Fig. 4. Direct comparison of normal and haemocytic leukemia cell proteins at equal protein load by low-cross linked SDS-PAGE (8\% $/ 1 \% \mathrm{C})$. Lane N, normal haemocytes; lane L, haemocytic leukemia cells; HMW, very high molecular weight protein(s); N and E, proteins characteristic of normal haemocytes and haemocytic leukemia cells, respectively.

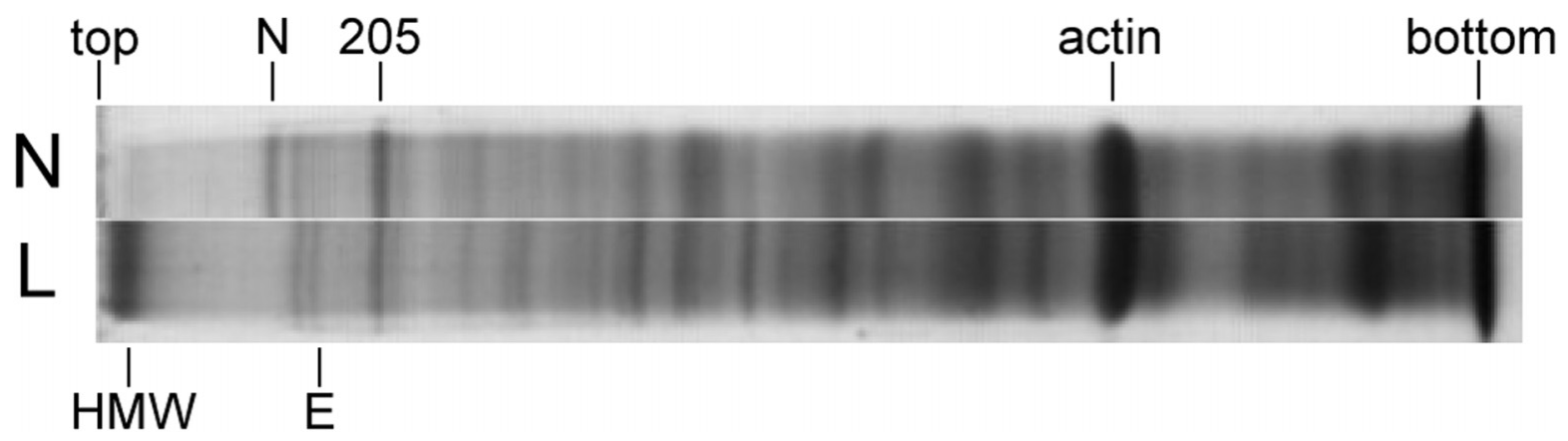

bulk of the raw sewage plume. Following a 6-month deployment, the mussels were recovered and brought to the field station. Any moribund or dead mussels were discarded. Haemolymph was subsequently analyzed as described in the Materials and methods. Mussels caged outside Pictou Harbour showed no haemocytic leukemia (MER) or a low prevalence of haemocytic leukemia (LP, 10\%). Based on previous work (Reinisch et al. 1984), $10 \%$ is considered background. Mussels caged for 6 months in the influence of raw sewage (PS1, PS2, PS3, and PS5) and bleached kraft pulpmill effluents (A) showed significantly elevated haemocytic leukemia levels compared with mussels caged at Merigomish $(\mathrm{KW}=106.176, p<0.001$ with $13 \mathrm{df} ; 0.05<p$ $<0.10$ multiple range test) (Table 2). At each of those sites, the proportion of mussels with haemocytic leukemia was at least $23 \%$ with a maximum of $56 \%$ at PS3, similar to the levels observed in the nearby wild population (34\%) (results not shown) (Table 2). Each haemolymph sample recorded as positive contained at least $50 \%$ cells that were specifically reactive with monoclonal antibody $1 \mathrm{E} 10$. These data show 
Table 1. Comparison of the reactivity of normal and leukemia Mytilus edulis and Mya arenaria hemocytes on immunoblots (Mya based on Stephens et al. (2001) and Kelley et al. (2001); Mytilus based on this study).

\begin{tabular}{lll}
\hline & Normal & Leukemia \\
\hline Mya arenaria & & \\
1E10 & - & + \\
2A4 & + & - \\
p53 & + & + \\
p63 & - & + \\
p73 & - & + \\
p97 & + & - \\
Mytilus edulis & & \\
1E10 & - & - \\
2A4 & - & - \\
p53 & nd & \\
p63 & \pm & + \\
p73 & \pm & + \\
p97 & \pm & + \\
p120 & \pm & + \\
\hline
\end{tabular}

Note: + , positive test; - , negative test; nd, not detectable; \pm , low.

that mussels placed in sites with industrial contaminants or municipal wastes had a statistically higher chance of developing haemocytic leukemia than mussels caged in clean sites.

\section{Discussion}

Bivalve molluscs develop proliferative anaplastic cells in the haemolymph that, in advanced stages, kill the host. As indicated in the Introduction, there is no clear agreement among experts concerning nomenclature, pathogenesis, ontogeny, or even the etiology of this unique disease. We have modified our use of leukemia to include the word haemocytic as recently suggested in correspondence from the Registry of Tumors in Lower Animals. Resolution of the exact diagnosis of this disease will require much more research using monoclonal antibodies that recognize distinct stages of differentiation among haemocyte subsets. Most importantly, the ontogeny of haemocytic leukemia cells will be elucidated by describing epitopes shared by both normal and fully differentiated tumour cells. The definition of individual genes and gene families critically important in the development and differentiation of subsets of cells will also resolve many questions concerning the ontogeny of end-stage tumour cells.

Haemocytic leukemia in M. edulis has been thoroughly documented throughout Canada, the United States, and Europe. The haemocytic leukemia cells of Mytilus share many phenotypic characteristics with haemocytic leukemia cells of Mya. Initially, a murine monoclonal antibody of Mytilus was developed by Noel et al. (1991). However, we used a different monoclonal antibody (1E10) to detect and characterize Mytilus haemocytic leukemia because the original monoclonal reagent is no longer available. Although 1E10 was initially generated to haemocytic leukemia cells of $M$. arenaria, confocal microscopy with extensive controls showed that $1 \mathrm{E} 10$ also specifically reacts with end-stage
Mytilus haemocytic leukemia cells. In contrast, there is no reactivity with normal $M$. edulis haemocytes. In fact, preliminary data from the laboratory show that $1 \mathrm{E} 10$ also reacts specifically with haemocytic leukemia cells but not normal haemocytes from of $M$. trossulus from Vancouver, British Columbia.

Comparative protein analyses show that haemocytic leukemia cells from Mytilus characteristically contain a 250$\mathrm{kDa}$ protein that is the likely equivalent of the Mya $1 \mathrm{E} 10$ antigen. The function of this $250-\mathrm{kDa}$ protein relative to the 300-kDa protein (N) characteristic of normal Mytilus or Mya haemocytes is unknown, although these may be reciprocally involved in cell adhesion. We will develop monoclonal antibodies to these distinctive proteins as well as to Mytilus haemocytic leukemia cells to further refine our ability to detect Mytilus haemocytic leukemia in the field.

On average, a given volume of haemolymph from Mytilus leukemic individuals yielded about 25 times as much cell protein as that from normal individuals. The corresponding normalized protein profiles closely resembled those already reported for 1E10-2A4 protein identification in $M$. arenaria (Stephens et al. 2001) haemocytes: the high molecular weight protein $(\mathrm{N})$ found only in normal cells, the slightly lower molecular weight protein $(\mathrm{E})$ found predominantly in haemocytic leukemia cells, plus the differential presence of a variety of additional smaller proteins of correlated size. However, the putative Mytilus equivalents of Mya 1E10 and 2A4 antigens (proteins E and A) were not cross-reactive after blotting, suggesting species differences or possible denaturation and neither were significantly glycoslyated, which may modify the epitope during renaturation. It is not uncommon for antibodies to cross-react with native proteins in cells but not with denatured proteins on blots or vice versa (e.g., the p53 family antibodies reported here).

Conversely, the lack of glycosylation and the fact that a 1E10 cross-reactive antigen in Mytilus can be detected in vesicles by immunofluorescence suggests that these cells are in the process of secreting the $1 \mathrm{E} 10$ surface antigen seen in fully expressed Mya haemocytic leukemia. Also as in Mya, the implication of increased mitotic activity is corroborated by the markedly greater tubulin content of haemocytic leukemia cells, but again, not to the same extent as in Mya, suggesting cells not yet at end stage. Comparative protein analysis, while valuable in initially documenting characteristic proteins at two extremes, is not particularly useful in evaluating cell populations in transition where the nature and number of individual cells must be determined. Clearly, more research is needed to establish which approach among immunofluorescence, immunoblots, and SDS-PAGE will ultimately be better suited for enviromental health assessments. Perhaps with the development of specific Mytilus MABs, and hence their potential greater reproducibility, immunofluorescence will be more suitable. However, strong arguments can also be put forth in favour of the later two approaches.

Western blot analyses demonstrate a significant similarity of Mytilus to Mya in that leukemic cells differentially express p63-p73 family members. This finding is particularly obvious with p63, a protein that has been associated with haemocytic leukemia (Yamaguchi et al. 2001) and stem cell proliferation (McKeon 2004). p73 has also been associated with malignant haematopoiesis (Freeborn et al. 2003). We 
Fig. 5. (A) Normal haemocyte, leukemic haemocyte, and a 1:1 mixture loaded at equal actin concentrations and analyzed by low-cross linked SDS-PAGE. Characteristic high molecular weight proteins distinguish normal (N) from haemocytic leukemia (E and $\mathrm{E}^{\prime}$ ) haemocytes. A major 205-kDa protein of unknown identity is common to both. Proteins $\mathrm{E}$ and $\mathrm{E}^{\prime}$ are the size equivalents of antigen $1 \mathrm{E} 10$ in Mya arenaria; A denotes a protein that is predominant in normal cells, the near size equivalent of antigen 2A4 in Mya. Asterisks denote other lower molecular weight proteins that distinguish the two cells types, also found in Mya normal versus haemocytic leukemia cells. (B) Magnification of the upper portion of Fig. 5A. (C) Densitometric traces of the lanes in Fig. 5B normalized to the position and amount of the common 205-kDa protein Solid line, haemocytic leukemia cells; dotted line, normal cells; dashed line, 1:1 mixture.

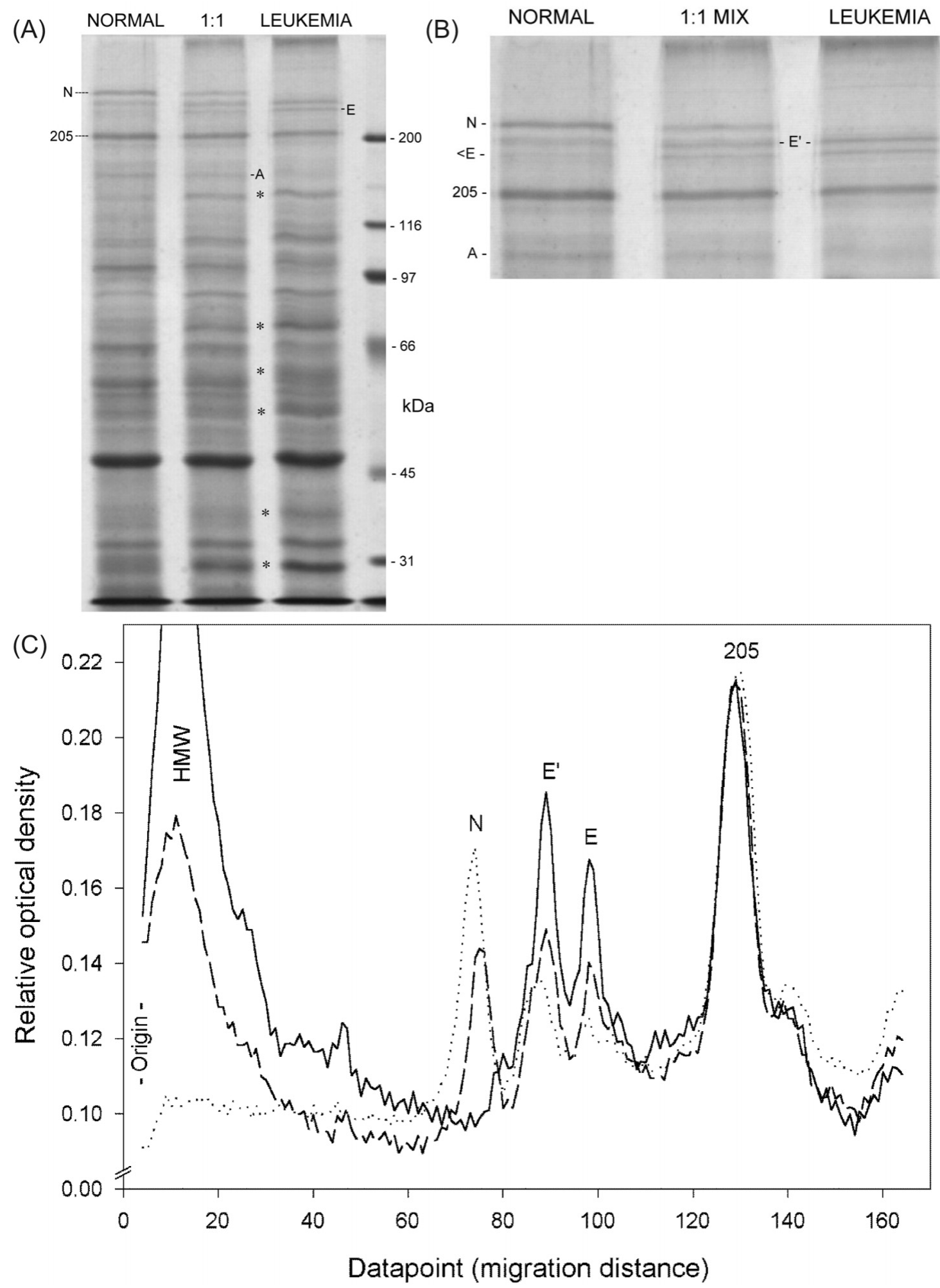


Table 2. Prevalence of leukemia in Mytilus edulis as obtained through visual readings with associated statistical results from a nonparametric two-tailed multiple comparison test using ranks and comparing all sites with Merigomish (MER) independently.

\begin{tabular}{|c|c|c|c|c|c|c|c|c|}
\hline Site & $N$ & $\begin{array}{l}\text { No. of animals } \\
\text { leukemic }\end{array}$ & Prevalence & Rank & SE & $Q$ & $\begin{array}{l}Q_{0.05,13}= \\
2.666\end{array}$ & $\begin{array}{l}Q_{0.1,13}= \\
2.424\end{array}$ \\
\hline PS1 & 28 & 7 & 25 & 7913.5 & 26.7454 & 2.435 & & $x$ \\
\hline PS2 & 50 & 13 & 26 & 14320.5 & 26.7228 & 2.578 & & $x$ \\
\hline PS3 & 52 & 29 & 56 & 1947.2 & 26.7154 & 5.875 & $x$ & \\
\hline PS4 & 62 & 5 & 8 & 14846.5 & 26.7218 & 0.822 & & \\
\hline PS5 & 33 & 10 & 30 & 9900.5 & 26.735 & 3.086 & $x$ & \\
\hline MP & 29 & 4 & 14 & 6467.5 & 26.7567 & 0.206 & & \\
\hline STMW & 30 & 3 & 10 & 7442 & 26.7486 & 1.143 & & \\
\hline NG & 42 & 8 & 19 & 11531.5 & 26.7296 & 2.135 & & \\
\hline LH & 30 & 3 & 10 & 7306.5 & 26.7496 & 0.974 & & \\
\hline Pulpmill A & 30 & 9 & 30 & 8869.5 & 26.7399 & 2.923 & $x$ & \\
\hline Pulpmill B & 30 & 7 & 23 & 8407.5 & 26.7425 & 2.346 & & \\
\hline PP & 30 & 4 & 13 & 7761.5 & 26.7464 & 1.541 & & \\
\hline LP & 30 & 3 & 10 & 7306.5 & 26.7496 & 0.974 & & \\
\hline Ref (MER) & 30 & 0 & 0 & 6525 & 26.7562 & & & \\
\hline
\end{tabular}

Note: $\times$ represents significantly elevated from reference.

expect that we will continue to detect p63-p73 as we explore more haemocytic leukemias within molluscan species.

In terms of molecular markers, the p53 gene family is ideal for investigating specific genetic targets of industrial contaminants in the field. This possibility was initially raised by Bhaskaran et al. (1999) who proposed using p53 as a genotoxic target in fish. Relative to molluscs, our work in New Bedford demonstrated that mutations in the p53 gene were detected when haemocytic leukemia cells of Mya were retrieved from a site heavily contaminated with polychlorinated biphenyls (Barker et al. 1997).

Why, in contrast with Mya, the different antibodies used do not detect a $53 \mathrm{kDa}$ p53 in immunoblots of Mytilus normal or haemocytic leukemia cells is unclear. The most obvious explanation is that the various antibodies used were not sensitive enough to detect low levels of p53 protein, although they will detect p53 in Mytilus tissues (data not shown). Secondly, while p53 mRNA may be abundant (Muttray et al. 2005), synthesis may be diminished or the protein degraded. Alternatively, p53 may be posttranslationally modified by ubiquitination (Brooks and $\mathrm{Gu}$ 2004) or SUMOylation (Minty et al. 2000; Cox et al. 2003), which is consistent with our detection of higher molecular weight forms.

Precisely what the leukemogenic agents are at the various sites in Pictou Harbour remains to be determined. The rapid induction of leukemia in caged bivalves in situ possibly resulting from the exposure to industrial effluents is an important finding and the development of disease in the caged individuals could reflect the overall health of the immediate aquatic environment. Although there is a possibility that a viral agent could have induced the haemocytic leukemia, the proximity of the cage to the different point sources coupled with the different levels of haemocytic leukemia found in cages closely situated (e.g., MP and PS2) strongly suggests that industrial and (or) municipal waste was the most likely source for the haemocytic leukemia induction. Marine invertebrates such as M. edulis are excellent monitors of the environment, since they are sessile filter feeders. Moreover, the fact that these animals develop leukemia within 6 months makes them ideal candidates to study molecular and cellular mechanisms of environmental carcinogenesis within a relatively short period. In our current work, we have deployed more mussels at fewer sites to enable in-depth diagnostics using 1E10, and newer MABs are being developed. Clearly, industrial wastes induce major changes in Mytilus including increased microbial infections (Tay et al. 2003) and concomitant suppressed haemocyte function (St-Jean et al. 2003).

Relative to molecular analyses, both the Mytilus and Mya models strongly suggest that the upregulation of p63-p73 is far more important in the leukemic process than is p53 expression. As our research expands into Vancouver Harbour using Mytilus, we will continue to focus on the expression of the entire p53 gene family with the expectation that p63-p73 will be diagnostically upregulated in end-stage haemocytic leukemia cells. As our data reveal, molluscan tumours continue to provide extremely valuable clues not only about environmental health but also about molecular mechanisms controlling cell transformation.

\section{Acknowledgements}

We are grateful to Ms. Kay Kim (Environment Canada, Dartmouth, Nova Scotia) who encouraged and helped us design and carry out the field experiment. The authors thank Mr. Joe van Buskirk of Kimberly Clark, Nova Scotia, for the use of the field microscope and laboratory, as well as the crew of the Customs House Inn for their support and patience. We also thank Dr. Rachel Cox and Dr. Annette Muttray for reviewing this manuscript prior to submission. We also extend our deepest appreciation to Mr. Louis Kerr for his excellent skills and assistance with the confocal microscope. This research was funded in part by the Pictou Harbour Biomonitoring Project, Fisheries and Oceans Canada, and Environment Canada.

\section{References}

Alonso, A., Suarez, P., Alvarez, C., San Juan, F., and Molist, P. 2001. Structural study of a possible neoplasia detected in 
Mytilus galloprovincialis collected from the Ria of Vigo (NW Spain). Dis. Aquat. Org. 47: 73-79.

Barker, C.M., Calvert, R.J., Walker, C.W., and Reinisch, C.L. 1997. Detection of mutant p53 in clam leukemia cells. Exp. Cell Res. 232: 49-57.

Bhaskaran, A., May, D., Rand-Weaver, M., and Tyler, C.R. 1999. Fish p53 as a possible biomarker for genotoxins in the aquatic environment. Environ. Mol. Mutagen. 33: 177-184.

Bower, S.M. 1989. The summer mortality syndrome and hemocytic neoplasia in blue mussels (Mytilus edulis) from British Columbia. Can. Tech. Rep. Fish. Aquat. Sci. No. 1703.

Brooks, C.L., and Gu, W. 2004. Dynamics in the p53-Mdm2 ubiquitination pathway. Cell Cycle, 3: 895-899.

Brousseau, D.J. 1987. Seasonal aspects of sarcomatous neoplasia in Mya arenaria (softshell clam) from Long Island Sound. J. Invertebr. Pathol. 50: 269-276.

Camplans, M., Gonzalez, M., and Rojas, P. 1998. Neoplasia in Mytilus chiliuasis cultivated in Chiloe Island (Chile). Bull. Eur. Assoc. Fish Pathol. 18: 93-95.

Cox, R.L., Stephens, R.E., and Reinisch, C.L. 2003. p63/73 homologues in surf clam: novel signalling motifs and implications for control of expression. Gene, 320: 49-58.

Dalziel, J.A., Yeats, P.A., and Loring, D.H. 1993. Water chemistry and sediment core data from Pictou Harbour and the East River Estuary. Can. Tech. Rep. Fish. Aquat. Sci. No. 1917.

Dunn, S.D. 1985. Effects of the modification of transfer buffer composition and the renaturation of proteins in gels on the recognition of proteins on western blots by monoclonal antibodies. Anal. Biochem. 157: 144-153.

Elston, R.A., Kent, M.L., and Drum, S.A. 1988. Progression, lethality, and remission of hemic neoplasia in the bay mussels, Mytilus edulis. Dis. Aquat. Org. 4: 135-142.

Fairbanks, G., Steck, T., and Wallach, D.F.H. 1971. Electrophoretic analysis of the major peptides of the human erythrocyte. Biochemistry, 10: 2602-2617.

Farley, C.A. 1969. Sarcomatid proliferative disease in a wild population of blue mussels (Mytilus edulis). J. Natl. Cancer Inst. 43: 509-516.

Farley, C.A., Otto, S.V., and Reinisch, C.L. 1986. New occurrence of epizootic sarcoma in Chesapeake Bay soft shell clams, Mya arenaria. Fish. Bull. 84: 851-857.

Freeborn, W.J., Smith, J.L., Chaudry, S.S., Haggerty, C.M., and Garder, K. 2003. Novel cell-specific and dominant anti-apoptic roles of p73 in transformed leukemia cells. J. Biol. Chem. 278: 2249-2255.

Gozes, I., and Barnstable, C.J. 1982. Monoclonal antibodies that recognize discrete forms of tubulin. Proc. Natl. Acad. Sci. U.S.A. 79: 2579-2583.

Green, M., and Alderman, D.J. 1983. Neoplasia in Mytilus edulis L. from United Kingdom waters. Aquaculture, 30: 1-10.

Harlow, E., Crawford, L.V., Pim, D.C., and Williamson, N.M. 1981. Monoclonal antibodies specific for simian virus 40 antigens. J. Virol. 39: 861-869.

Hillman, R.E. 1993. Relationship of environmental contaminants to occurrence of neoplasia in Mytilus edulis populations from east and west coast mussels watch sites. J. Shellfish Res. 12: 109.

Jessen-Eller, K., Kreiling, J.A., Begley, G.S., Steele, M.E., Walker, C.W., Stephens, R.E., and Reinisch, C.L. 2002. A new invertebrate member of the p53 gene family is developmentally expressed and responds to polychlorinated biphenyls. Environ. Health Perspect. 110: 377-385.

Kelley, M.L., Winge, P., Heaney, J.D., Stephens, R.E., Farell, J.H., van Beneden, R.J., Reinisch, C.L., Lesser, M.P., and Walker, C.W. 2001. Expression of homologues for p53 and p73 in the softshell clam (Mya arenaria), a naturally-occurring model for human cancer. Oncogene, 20: 748-758.

Krishnakumar, P.K., Casillas, E., Snider, R.S., Kagley, A.N., and Varanasi, U. 1999. Environmental contaminants and the prevalence of hemic neoplasia (leukemia) in the common mussel (Mytilus edulis complex) from Puget Sound, Washington, USA. J. Invertebr. Pathol. 73: 135-146.

Laemmli, U.K. 1970. Cleavage of structural proteins during the assembly of the head of bacteriophage T4. Nature (Lond.), 227: 680-685.

Mallet, A.L., and Carver, C.E. 1995. Comparative growth and survival patterns of Mytilus trossulus and Mytilus edulis in Atlantic Canada. Can. J. Fish. Aquat. Sci. 52: 1873-1880.

McGladdery, S.E., and Bower, S.M. 1999. Synopsis of infectious diseases and parasites of commercially exploited shellfish: malpeque disease of oysters. Available from http://www.pac.dfo-mpo.gc.ca/ sci/shelldis/pages/maldisoy_e.html [accessed 21 August 2005; updated 19 October 1999].

McGladdery, S.E., Reinisch, C.L., MacCullum, G.S., Stephens, R.E., Walker, C.L., and Davidson, J.T. 2001. Haemic neoplasia in soft-shell clams (Mya arenaria): recent outbreaks in Atlantic Canada and discovery of a p53 gene homologue associated with the condition. Bull. Aquacult. Assoc. Can. 101: 19-26.

McKeon, F. 2004. p63 and the epithelial stem cell: more than the status quo? Genes Dev. 18: 465-469.

Minty, A., Dumont, X., Kaghad, M., and Caput, D. 2000. Covalent midification of $73 \alpha$ by SUMO-1. J. Biol. Chem. 275: $36316-$ 36323.

Miosky, D.L., Smolowitz, R.M., and Reinisch, C.L. 1989. Leukemia cell specific protein of the bivalve mollusc Mya arenaria. J. Invertebr. Pathol. 53: 32-40.

Mix, M.C. 1983. Haemic neoplasms of bay mussels, Mytilus edulis L., from Oregon; occurrence, prevalence, seasonality and histopathological progression. J. Fish Dis. 6: 239-248.

Muttray, A.F., Cox, R.L., St-Jean, S., van Poppelen, P., Reinisch, C.L., and Baldwin, S.A. 2005. Identification and phylogenetic comparison of p53 in two distinct mussel species (Mytilus). Comp. Biochem. Physiol. C Toxicol. Pharmacol. 140(2): 237250.

Noel, D., Boulo, V., Chagot, D., Mialhe, E., Paolucci, F., Clavies, C., Hervaud, E., and Elston, R. 1991. Preparation and characterization of monoclonal antibodies against neoplastic haemocyte of Mytilus edulis (Bivalvia). Dis. Aquat. Org. 10: 51-58.

Noel, D., Pipe, R., Elston, R., Bachere, E., and Mialhe, E. 1994. Antigenic characterization of haemocyte subpopulations in the mussel Mytilus edulis by means of monoclonal antibodies. Mar. Biol. 119: 549-556.

Oprandy, J.J., Chang, P.W., Pronovost, A.D., Cooper, K.R., Brown, R.S., and Yates, V.J. 1981. Isolation of a viral agent causing hematopoietic neoplasia in the soft-shell clam, Mya arenaria. J. Invertebr. Pathol. 38: 45-51.

Painter, H.G., and Stewart, P.L. 1992. An assessment of the environmental quality of Pictou Harbour and surrounding watershed. Prepared for the Advisory Committee and the Technical Committee of the Pictou Harbour Environmental Action Plan. Report available from Environment Canada, Atlantic Region library, Dartmouth, N.S.

Prouse, N.J. 1994. Ranking harbours in the Maritime provinces of Canada for potential to contaminate American lobster (Homarus americanus) with polycyclic aromatic hydrocarbons. Can. Tech. Rep. Fish. Aquat. Sci. No. 1960.

Rasmussen, L.P.D. 1996. Occurrence, prevalence and seasonality of neoplasia in the marine mussel Mytilus edulis from three sites in Denmark. Mar. Biol. 92: 59-64. 
Reinisch, C.L., Charles, A.M., and Troutner, J. 1983. Unique antigene on neoplastic cells of the soft shell clam Mya arenaria. Dev. Comp. Immunol. 7: 33-39.

Reinisch, C.L., Charles, A.M., and Stone, A.M. 1984. Epizootic neoplasia of soft shell clams collected from New Bedford. Hazard. Waste, 1: 73-81.

Stephens, R.E. 1997. Synthesis and turnover of embryonic sea urchin ciliary proteins during selective inhibition of tubulin synthesis and assembly. Mol. Biol. Cell, 8: 2187-2198.

Stephens, R.E., Walker, C.W., and Reinisch, C.L. 2001. Multiple protein differences distinguish clam leukemia cells from normal haemocytes: evidence for the involvement of p53 homologues. Comp. Bichem. Physiol. C Toxicol. Pharmacol. 129: 329-338.

St-Jean, S.D., Courtenay, S.C., Pelletier, E., and St-Louis, R. 1999. Butyltin concentration in sediments and blue mussels (Mytilus edulis) of the southern Gulf of St. Lawrence, Canada. Environ. Technol. 20: 181-189.

St-Jean, S.D., Courtenay, S.C., and Parker, R.W. 2003. Immunomodulation in blue mussels (Mytilus edulis) exposed to a pulp and paper mill effluent in eastern Canada. Water Qual. Res. J. Can. 38: 647-666.
Tay, K.L., Teh, S.J., Doe, K., Lee, K., and Jackman, P. 2003. Histopathologic and histochemical biomarker responses of Baltic clam, Macoma baltica, to contaminated Sydney Harbour sediment, Nova Scotia, Canada. Environ. Health Perspect. 111: 273-280.

White, M.K., Miosky, D., Flessas, D.A., and Reinisch, C.L. 1993. The expression of an adhesion-related protein by clam haemocytes. J. Invertebr. Pathol. 61: 253-259.

Wong, C.S., Cretney, W.J., and Cosson-Mannevy, M.M. 1984. Putative neoplastic disorders in mussels (Mytilus edulis) from southern Vancouver Island water, British Columbia. J. Invertebr. Pathol. 44: 157-160.

Yamaguchi, H., Inokuchi, K., and Dan, K. 2001. Mutation of the p51/p63 gene is associated with blastic crisis in chronic myelogenous leukemia. Leukemia, 15: 1729-1734.

Zar, J. 1984. Biostatistical analysis. Prentice-Hall, Inc., Englewood Cliffs, N.J.

Zizzo, N., Tiscae, P.G., and Troncone, A. 1991. Neoplastic disease in mussels (Mytilus galloprovincialis). Boll. Soc. Ital. Patol. 7: 19. 